\title{
Wewnętrzne i zewnętrzne czynniki skutecznej realizacji „Narodowego programu zdrowia”
}

\begin{abstract}
Internal and external factors determining effective implementation of the National Health Programme: This article explores various factors that affect implementation of the Polish health strategy, namely National Health Programme (NHP). On the basis of the concept of the Health Policy Triangle, the authors identify several factors of effective implementation of the NHP for the years 2016-2020 under the current legislation and organisational conditions. Those factors are divided into two groups: internal (dependant on NHP policy document) and external ones (related to legal and organisational context of programme's implementation). Next, each factor is briefly characterised to provide some general guidance for the NHP for the next period. The final part of the article contain a list of proposed actions and decisions to be taken in order to ensure higher effectiveness of the next NHP.
\end{abstract}

Słowa kluczowe: zdrowie publiczne, polityka zdrowotna w Polsce, „Narodowy program zdrowia"

Keywords: public health, health policy in Poland, National Health Programme

* Doktor nauk medycznych, specjalista zdrowia publicznego, adiunkt w Szkole Zdrowia Publicznego Centrum Medycznego Kształcenia Podyplomowego wWarszawie; e-mail: jgrudziaz@cmkp.edu.pl.

** Radca prawny, główny specjalista w Ministerstwie Sprawiedliwości, doktorant w Kolegium Prawa Akademii Leona Koźmińskiego w Warszawie; e-mail: kuba.sekowski@ms.gov.pl.

\section{Wstęp}

Polityka zdrowotna powinna stanowić zespół nieprzerwanych i powtarzających się cyklicznie programów ${ }^{1}$. Działania obejmujące planowanie, realizację, monitorowanie i ewaluację w ramach poszczególnych cykli powinny się przy tym

1 S.F. Shell i in., Public health program capacity for sustainability: a new framework, „Implementation Science" 2013, nr 8, s. 15. 
nakładać i z siebie wynikać2. Oznacza to konieczność ciągłej analizy obecnie realizowanego planu w celu optymalnego przygotowania i przeprowadzenia działań w kolejnej edycji programów.

Obowiązujący „Narodowy program zdrowia na lata 2016-2020” (dalej: NPZ) jest pierwszym dokumentem stanowiącym naczelny plan zdrowotny państwa (ang. master plan $)^{3}$ przyjętym na podstawie długo oczekiwanej ustawy o zdrowiu publicznym ${ }^{4}$. Inaczej niż poprzednie programy, które były przyjmowane w drodze uchwał rządowych lub decyzji Ministra Zdrowia ${ }^{5}$, aktualny NPZ został wprowadzony na mocy rozporządzenia Rady Ministrów, a zatem aktu prawa powszechnie obowiązującego.

W okresie poprzedzającym uchwalenie ustawy o zdrowiu publicznym i przyjęcie obecnego NPZ podstawowe zagadnienia polityki zdrowotnej pozostawały w sferze dyskrecjonalnych decyzji władz publicznych. Miały one dowolność w określeniu kierunków i celów podejmowanych działań. Konsekwencją stosunkowo słabego umocowania prawnego poprzednich NPZ, a także braku wyodrębnionych środków na ich realizację, było ograniczenie znaczenia tych programów do roli informacyjnej i inspirującej. Programy te zawierały często rozbudowane diagnozy stanu zdrowia ludności, opisywały znaczenie poszczególnych grup chorób w bilansie stanu zdrowia populacji oraz wskazywały kierunki przeciwdziałania zidentyfikowanym problemom zdrowotnym. Informacje te były podstawą działań podmiotów publicznych - głównie jednostek samorządu terytorialnego (dalej: JST) oraz organizacji pozarządowych ${ }^{6}$.

Analizy dotychczasowych przedsięwzięć finansowanych ze środków publicznych ${ }^{7}$, podejmowanych $\mathrm{z}$ dobrymi intencjami, ale bez należytego przygotowania

2 W.K. Kellog, Foundation, Using Logic Models to Bring Together Planning, Evaluation, And Logic Model Development Guide, January 2004, https://www.wkkf.org/resource-directory/resource/2006/02/wk-kellog-foundation-logic-model-development-guide [dostęp: 10 stycznia 2018 r.].

3 T.R. Oliver, The politics of public health policy, „Annual Review of Public Health” 2006, nr 27, s. 195-233, https://dx.doi.org/10.1146/annurev.publhealth.25.101802.123126.

${ }^{4}$ Ustawa z 11 września 2015 r. o zdrowiu publicznym, t.j. Dz.U. 2018, poz. 1492. Zob. także M. Dercz, H. Izdebski, Prawne aspekty organizacji i funkcjonowania systemu zdrowia publicznego w Polsce (Analiza prawa ustrojowego, materialnego i formalnego), Warszawa 2015.

5 „Narodowy program zdrowia na lata 1996-2005” przyjęty przez Ministra Zdrowia 3 września 1996 r.; „Narodowy program zdrowia na lata 2007-2015” przyjęty uchwałą nr 90/2007 Rady Ministrów z 15 maja 2007 r.

${ }^{6}$ H. Izdebski, Podstawy prawne ustroju zdrowia publicznego w Polsce, „Zdrowie Publiczne" 2001, nr 111(5-6), s. 367-379.

7 A. Leśniewska i in., Działania powiatów w zakresie profilaktyki i promocji zdrowia w Polsce - w świetle badań ankietowych, „Hygeia Public Health” 2014, nr 49(3), s. 472-477; NIK, „Realizacja programów polityki zdrowotnej przez jednostki samorządu terytorialnego”, informacja o wynikach kontroli, Warszawa 2016, https://www.nik.gov.pl/kontrole/P/15/063/ [dostęp: 20 sierpnia 2018 r.]. 
warsztatowego, wskazywały na ich niską efektywność, a często na brak pomiaru efektywności. Stanowiło to poważne zagrożenie w realizacji, a jednocześnie trudność w ocenie skuteczności polityki w zakresie zdrowia publicznego. W literaturze powszechnie wskazywano również na niedostatki dotyczące koordynacji prowadzonych działań ${ }^{8}$ oraz brak ich ciągłości ${ }^{9}$.

W tym kontekście wejście w życie ustawy o zdrowiu publicznym oraz wynikające z niej normatywne uregulowanie zakresu i celu NPZ miały stanowić odpowiedź na obserwowane niedomagania i umożliwić efektywną realizację polityki zdrowotnej w Polsce ${ }^{10}$. Oczekiwano przede wszystkim urzeczywistnienia zasady współpracy międzysektorowej, intensyfikacji działań z zakresu promocji zdrowia i profilaktyki oraz działań nakierowanych na zmniejszanie nierówności w zdrowiu ${ }^{11}$.

Perspektywa trzech lat obowiązywania obecnego NPZ nie pozwala w pełni ocenić, na ile program ten spełni pokładane w nim nadzieje. Możliwe jest jednak wskazanie podstawowych czynników warunkujących skuteczność wdrażania aktualnego NPZ i osiąganie zakładanych celów polityki zdrowotnej państwa. Zwrócenie uwagi na zagrożenia realizacji NPZ na lata 2016-2020 może pozwolić na lepsze przygotowanie kolejnej edycji programu. Dlatego celem niniejszego artykułu będzie wskazanie obszarów i uwarunkowań / czynników, które mogą być zagrożeniami realizacji NPZ na lata 2016-2020, oraz propozycji odpowiadających im rozstrzygnięć politycznych i prawnych, które powinny się przyczynić do sprawniejszej realizacji NPZ na lata 2021-2025.

\section{Tworzenie polityki zdrowotnej}

Według powszechnie przyjętej koncepcji trójkąta polityki zdrowotnej (health policy triangle) G. Walt i L. Gilsona na kształt polityki zdrowotnej wpływ mają jej zawartość (content), kontekst/okoliczności (context), procesy i strategie (process) oraz interesariusze (actors), zob. wykres $1^{12}$.

8 J. Nosko, O potrzebie ustawy o zdrowiu publicznym, „Zdrowie Publiczne” 2001, nr 111(2), s. 75-80.

9 D. Cianciara i in., Trwałość samorządowych programów zdrowotnych, „Hygeia Public Health" 2015, nr 50(1), s. 104-111.

10 J. Grudziąż-Sękowska, K. Sękowski, D. Cianciara, Ustawa o zdrowiu publicznym nowa jakość?, „Postępy Nauk Medycznych” 2016, t. XXIX(5), s. 337-343.

11 Protokół ze spotkania dotyczącego przyszłości zdrowia publicznego w Polsce, http:// www.prezydent.pl/archiwum-lecha-kaczynskiego/aktualnosci/rok-2008/art,148,5,spotkanie-w-palacu-prezydenckim-dotyczace-przyszlosci-zdrowia-publicznego-w-polsce.html [dostęp: 20 sierpnia 2018 r.].

12 G. Walt, L. Gilson, Reforming the health sector in developing countries: the central role of policy analysis, „Health Policy and Planning” 1994, nr 9(4), s. 353-370. 


\section{Wykres 1. Trójkąt polityki zdrowotnej}

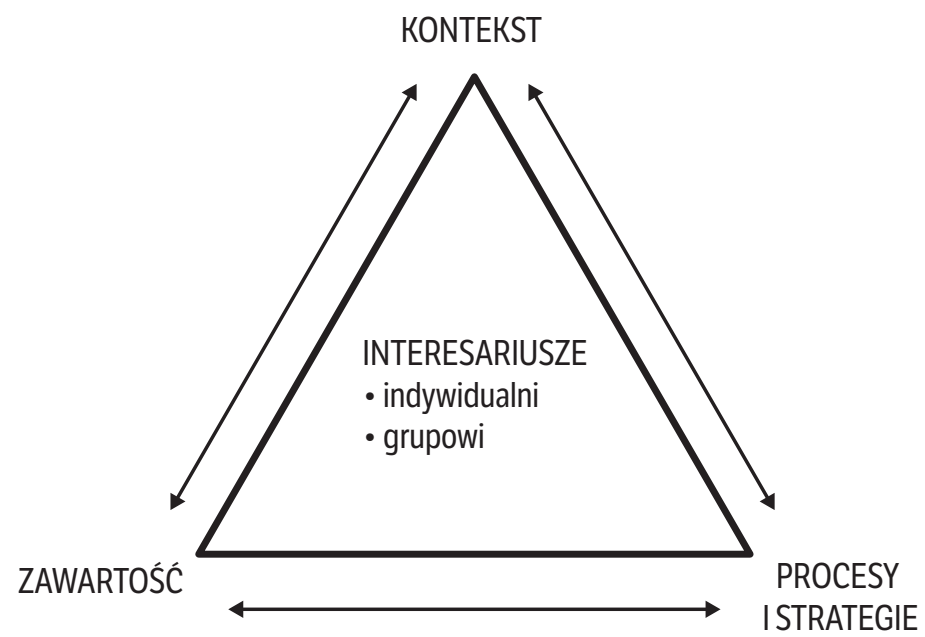

Źródło: na podstawie G. Walt, L. Gilson, Reforming the health sector in developing countries: the central role of policy analysis, „Health Policy and Planning” 1994, nr 9(4), s. 353-370.

W obowiązującym stanie prawnym NPZ stanowi narzędzie polityki zdrowotnej państwa (władz centralnych i samorządowych) oraz udziału w realizacji polityki zdrowotnej podmiotów niepublicznych. Zakres programu wynika wprost z przepisów ustawy o zdrowiu publicznym i bez jej nowelizacji nie może zostać zmieniony. Zgodnie z ustawą o zdrowiu publicznym w NPZ formułowane są kluczowe elementy polityki rozumianej jako uzgodniony między interesariuszami plan działania w celu rozwiązania określonego problemu. Są to: cel strategiczny, cele operacyjne, zadania realizujące cele operacyjne, podmioty odpowiedzialne za realizację zadań i realizatorzy zadań, tryb i wysokość finansowania zadań oraz wskaźniki i sposób monitorowania i ewaluacji programu. Ustawa o zdrowiu publicznym przewiduje przy tym cykliczność NPZ przez wskazanie minimalnego okresu jego obowiązywania na 5 lat. Jednocześnie poza NPZ normowane są inne kwestie dotyczące warunków jego realizacji. Rozwiązania te należy uznać za względnie niezmienne w średnim okresie - odpowiadającym realizacji obecnego i kolejnego NPZ. Wyznaczają formalne ramy przyszłego NPZ oraz zakres decyzji, które warunkować będą skuteczność jego realizacji.

Zastosowanie koncepcji trójkąta polityki zdrowotnej, przy uwzględnieniu wskazanych uwarunkowań prawnych i organizacyjnych realizacji polityki zdrowotnej w Polsce, pozwala wyróżnić dwie główne grupy czynników warunkujących skuteczną realizację przyszłego NPZ. Czynniki z obszaru wewnętrznego - wynikające ze struktury i zawartości samego dokumentu programu (rozporządzenia RM), które odpowiadają „zawartości” z modelu G. Walta 
i L. Gilsona, oraz czynniki z obszaru zewnętrznego - związane z otoczeniem programu, które odpowiadają „kontekstowi” realizowanej polityki zdrowotnej. W obydwu tych obszarach występowanie i nasilenie poszczególnych czynników jest pochodną obowiązujących regulacji prawnych i wyborów o charakterze politycznym. Wyodrębnione w ten sposób czynniki umieszczono w tabeli 1.

Tabela 1. Wybrane aspekty skutecznej realizacji NPZ - czynniki wewnętrzne i zewnętrzne oraz konieczne zmiany organizacyjne i prawne

\begin{tabular}{|c|c|c|}
\hline \multirow{2}{*}{ Czynniki wewnętrzne } & NPZ 2016-2020 & \multirow[b]{2}{*}{ Czynniki zewnętrzne } \\
\hline & & \\
\hline $\begin{array}{l}\text { Wskazanie i parametryzacja } \\
\text { celów programu }\end{array}$ & & $\begin{array}{l}\text { Zapewnienie sprawnej } \\
\text { koordynacji i monitorowania } \\
\text { NPZ }\end{array}$ \\
\hline $\begin{array}{l}\text { Precyzyjne określenie } \\
\text { realizatorów zadań NPZ }\end{array}$ & $\begin{array}{c}\text { Decyzje o charakterze } \\
\text { politycznym }\end{array}$ & $\begin{array}{l}\text { Urzeczywistnienie zasady } \\
\text { Health in All Policies }\end{array}$ \\
\hline Ujednolicenie struktury NPZ & $\begin{array}{l}\text { Zmiany w regulacjach } \\
\text { prawnych }\end{array}$ & $\begin{array}{l}\text { Zapewnienie ciągłości realizo- } \\
\text { wanej polityki zdrowotnej }\end{array}$ \\
\hline $\begin{array}{l}\text { Bezpośrednie odniesienie się } \\
\text { do problemu zmniejszenia } \\
\text { nierówności w zdrowiu }\end{array}$ & & Niezależna ewaluacja \\
\hline $\begin{array}{l}\text { Właściwy dobór wskaźników } \\
\text { monitorowania i ewaluacji }\end{array}$ & & \\
\hline & NPZ 2021-2025 & \\
\hline
\end{tabular}

\section{Czynniki o charakterze wewnętrznym}

Zarówno w literaturze, jak i wśród praktyków zdrowia publicznego brak jest powszechnie przyjętych kryteriów oceny dokumentów programowych polityki zdrowotnej ${ }^{13}$, a tym samym ustalonego, wynikającego z samego dokumentu, zestawu czynników warunkujących skuteczność opisywanej w nim polityki zdrowotnej. Formułowane są często odmienne oczekiwania, co do formy i zawartości dokumentów polityki zdrowotnej, a poszczególnym ich elementom przypisywane jest różne znaczenie z punktu widzenia efektywności realizacji polityki zdrowotnej. W tworzeniu polityki zdrowotnej zauważa się konflikt między potrzebami i możliwościami. Spojrzenie z różnych perspektyw (decydentów, naukowców, realizatorów, interesariuszy czy wreszcie podmiotu dokonującego oceny) oraz różne podejścia do oceny (dotyczące możliwości organizacyjnych, efektywności ekonomicznej, analizy efektów czy oceny wieloaspektowej)

13 D. Cianciara, J. Grudziąż-Sękowska, Dylematy oceny polityki zdrowotnej - przegląd piśmiennictwa międzynarodowego, „Hygeia Public Health” 2016, nr 51(3), s. 235-241; D.H. Gleeson, D.G. Legge, D. O'Neill, Evaluating health policy capacity: Learning from international and Australian experience, „Australia and New Zealand Health Policy” 2009, nr 6, s. 3. 
pokazują złożoność problemu oraz często brak zgodności co do metodologii i zasad dokonywania takiej oceny ${ }^{14}$. Jednakże, uwzględniając wyniki krytycznej analizy obecnego NPZ, możliwe jest wyróżnienie pięciu najważniejszych zagadnień problemowych, których właściwe uregulowanie w przyszłym NPZ może w znacznym stopniu przyczynić się do wzrostu efektywności realizowanej polityki zdrowotnej.

\section{Wskazanie i parametryzacja celów programu}

Podstawowym zarzutem, jaki można sformułować wobec obecnie realizowanego NPZ, jest niedostatecznie precyzyjne określenie celu strategicznego programu. Jako cel strategiczny zostało wskazane: wydlużenie życia $w$ zdrowiu, poprawa zdrowia i związanej z nim jakości życia ludności oraz zmniejszenie nierówności społecznych $w z$ drowiu. Takie sformułowanie stanowi praktycznie dosłowne powtórzenie przepisu ustawy o zdrowiu publicznym. Z tego względu zgłaszany jest również zarzut niepełnego wykonania upoważnienia ustawowego ${ }^{15}$.

Biorąc pod uwagę znaczenie prawidłowego wskazania celu najwyższego szczebla dla poprawnego sformułowania celów i zadań na niższych szczeblach planowania, takie ujęcie celu strategicznego stanowi istotny problem. Główny cel programu powinien przynajmniej zawierać informacje o beneficjentach podejmowanych działań, przewidywanych korzyściach i czasie, w którym one wystąpią. Ma to istotne znaczenie dla wytyczania konkretnych zadań NPZ.

Warto przy tym podkreślić, że przewidziane w programie działania w różnym stopniu przyczyniać się będą do osiągnięcia poszczególnych elementów celu strategicznego, ale czasem mogą wręcz wywoływać przeciwne skutki. Adresowane do określonej populacji działania nakierowane na poprawę stanu zdrowia mogą prowadzić do zwiększenia nierówności w zdrowiu z perspektywy całego społeczeństwa ${ }^{16}$. Dodatkowo podejmowanie przewidzianych w NPZ działań prawie zawsze odbywa się w warunkach konkurencji o dostępne zasoby, przede wszystkim o finansowanie. $Z$ tego względu brak precyzyjnego określenia i parametryzacji (tzn. dokonywania kompleksowej oceny na podstawie szczegółowych parametrów i kryteriów) celu strategicznego (a dokładniej jego elementów składowych) w połączeniu z niedostępnością efektywnych mechanizmów bieżącej kontroli nad pojedynczymi działaniami może prowadzić do istotnych zakłóceń w realizacji programu.

${ }_{14}$ D. Cianciara, J. Grudziąż-Sękowska, Dylematy oceny polityki zdrowotnej, op. cit.

15 J. Grudziąż-Sękowska, K. Sękowski, Analiza sprawnościowa możliwości realizacji NPZ - aspekty prawne [w:] Ekspercka strategia wspomagania realizacji NPZ 2016-2020 w zakresie ograniczania społecznych nierówności $w$ zdrowiu $z$ wykorzystaniem funkcji i instytucji zdrowia publicznego, red. P. Tyszko, M. Bogdan, Konsorcjum Nauka i Zdrowie, Warszawa 2017, s. 61-97.

${ }^{16}$ D. Cianciara, Przyczyny i przyczyny przyczyn nierówności $w$ zdrowiu, „Hygeia Public Health" 2015, nr 50(3), s. 435-440. 
Podobnie jak w odniesieniu do celu strategicznego konieczne jest określenie oczekiwanych rezultatów dla poszczególnych celów operacyjnych. Powinny być one wskazane w kategoriach mierzalnych i umożliwiać ocenę wpływu podejmowanych działań na występowanie i skalę różnic w stanie zdrowia grup docelowych.

\section{Precyzyjne określenie realizatorów zadań NPZ}

Zgodnie $\mathrm{z}$ art. 3 ustawy o zdrowiu publicznym zadania z zakresu zdrowia publicznego są wykonywane zarówno przez szeroko rozumiane organy władzy publicznej, jak i organizacje pozarządowe, w tym podmioty prowadzące działalność pożytku publicznego, których cele statutowe lub przedmiot działalności są zbieżne z zadaniami z zakresu zdrowia publicznego ${ }^{17}$.

W realizowanym obecnie NPZ wskazanie realizatorów nastąpiło w pierwszej kolejności na poziomie celów operacyjnych. W programie przewidziano przy tym różną ich liczbę - od trzech w przypadku 6. celu operacyjnego do kilkudziesięciu w przypadku 4. celu operacyjnego. W podobny sposób wskazano realizatorów poszczególnych zadań. W wielu miejscach wskazanie realizatorów nastąpiło przez wskazanie całej grupy podmiotów, np. wszystkich lub wybranych szczebli JST ${ }^{18}$.

Do określenia wzajemnego stosunku realizatorów posłużono się określeniem „we współpracy”, które nie pozwala precyzyjnie określić roli poszczególnych podmiotów, których liczba może być stosunkowo duża. Niejasny pozostaje zatem stosunek między podmiotami wskazanymi jako odpowiedzialne w tych samych celach operacyjnych.

Biorąc pod uwagę, że sprawność realizacji projektu zależy od precyzyjnego określenia w nim ról poszczególnych uczestników, w tym wskazania kto podejmuje decyzje i jest odpowiedzialny za projekt jako całość (accountability), a kto odpowiada za wykonanie określonych zadań (responsibility), przyjęty w NPZ sposób wskazania realizatorów może negatywnie rzutować na sprawność oraz efektywność jego wdrożenia. Zastosowane rozwiązania ograniczają też faktyczny zakres realizacji deklarowanej woli zaangażowania w działania na rzecz zdrowia i skoordynowania działań możliwie dużej liczby podmiotów ${ }^{19}$.

\section{Ujednolicenie struktury NPZ}

Przewidziane w analizowanym NPZ zadania zostały wskazane odrębnie dla każdego z celów operacyjnych, co odpowiada formalnym wymaganiom ustawy o zdrowiu publicznym. W ramach poszczególnych zadań wyróżnione zostały

17 Ustawa z 11 września 2015 r. o zdrowiu publicznym, t.j. Dz.U. 2018, poz. 1492.

18 Rozporządzenie Rady Ministrów z 4 sierpnia 2016 r. w sprawie Narodowego Programu Zdrowia na lata 2016-2020, Dz.U. poz. 1492.

19 Uzasadnienie rządowego projektu ustawy o zdrowiu publicznym, druk sejmowy nr 3675/VII kad. 
działania, przy czym rozróżnienie zadań i działań nie wynika wprost z NPZ ani nie jest konsekwentnie stosowane w całym dokumencie. W niektórych miejscach po wprowadzeniu do wyliczenia, zapowiadającym zadania służące realizacji określonego celu operacyjnego, poszczególne punkty tego wyliczenia posługują się pojęciem zadania, $w$ innych zaś używane jest pojęcie działanie, które często dzieli się na dalsze, nienazwane części. Poszczególne zadania/działania zostały też opisane $\mathrm{z}$ różną szczegółowością.

Jednym z podstawowych celów ustawy o zdrowiu publicznym było stworzenie naczelnego planu zdrowotnego państwa. Konsekwencją tego założenia było, skądinąd słuszne, włączenie do NPZ, funkcjonujących wcześniej jako odrębne, programów dotyczących wybranych problemów zdrowotnych. Scaleniu w NPZ uległy zatem działania z zakresu polityki antyalkoholowej i antynarkotykowej oraz częściowo w odniesieniu do ochrony zdrowia psychicznego. Ich włączenie do NPZ przybrało jednak jedynie wymiar symboliczny, a poszczególne polityki zachowały praktycznie pełną odrębność.

Takie ukształtowanie struktury NPZ nie tylko jest niezgodne $\mathrm{z}$ deklarowanym celem ustawy o zdrowiu publicznym, jakim miało być skoordynowanie działań różnych podmiotów i w różnych obszarach zdrowia publicznego ${ }^{20}$, ale utrudnia podejmowanie działań służących realizacji więcej niż jednego celu operacyjnego oraz komplikuje proces sprawozdawczy. Zarazem nie jest to zgodne ze stanowiskiem Światowej Organizacji Zdrowia (WHO) odnośnie do zarządzania (governance) systemem zdrowia publicznego i całym systemem zdrowia ${ }^{21}$. Zasadny jest zatem postulat wprowadzenia w przyszłym NPZ zmian porządkujących jego strukturę wewnętrzną oraz funkcjonalne, a nie jedynie formalne, włączenie do programu działań dotyczących problematyki uzależnień.

\section{Bezpośrednie odniesienie się do problemu zmniejszenia nierówności w zdrowiu}

Zgodnie z ustawą o zdrowiu publicznym cel strategiczny NPZ powinien godzić dwa zasadnicze kierunki działań nakierowanych 1) na poprawę (średniego) poziomu zdrowia i 2) na zmniejszanie nierówności w zdrowiu. Działania te nie są tożsame, a często mają wręcz konkurencyjny charakter. W sytuacji ograniczonych zasobów, które mogą być przeznaczone na zadania przewidziane w NPZ, właściwe „rozłożenie akcentów” wynikać może właśnie z odpowiednio sformułowanego celu strategicznego. W razie braku takiego rozstrzygnięcia to aksjologiczne, a przede wszystkim alokacyjne wybory poszczególnych realizatorów przesądzą o ostatecznych rezultatach podejmowanych działań oraz o wynikających z nich długofalowych oddziaływaniach. Sytuacja taka naruszałaby porządek planowania strategicznego (poziom polityki, strategii, operacyjny, taktyczny).

\footnotetext{
${ }^{20}$ Ibidem.

${ }^{21}$ D. Cianciara i in., Essential public health operations in the WHO European Region, „Postępy Nauk Medycznych” 2016, t. XXIX(5), s. 316-321
} 
Pomimo obszerności obecnego NPZ, przewidziane w poszczególnych celach operacyjnych zadania nie do końca pokrywają się z zadaniami zdrowia publicznego wymienionymi w art. 2 ustawy o zdrowiu publicznym. Dotyczy to między innymi ograniczania nierówności w zdrowiu wynikających z uwarunkowań społeczno-ekonomicznych.

Zagadnienie nierówności zdrowotnych nie było dotychczas w Polsce przedmiotem dostatecznego zainteresowania ani ze strony badaczy, ani decydentów. Można tym częściowo uzasadnić brak precyzyjnego określenia na poziomie strategicznym oczekiwanych rezultatów wdrożenia NPZ w zakresie zmniejszania różnic w zdrowiu. Niemniej przypisana NPZ funkcja zasadniczego instrumentu polityki publicznej w obszarze ochrony zdrowia uzasadnia oczekiwanie wyczerpującego ujęcia w nim kwestii już wcześniej, na poziomie ustawy o zdrowiu publicznym, zidentyfikowanych jako istotne. Tymczasem kwestii nierówności w zdrowiu dotyczą, i to jedynie częściowo, 1.i 5. cel operacyjny. Problem stanowi również fakt, że wskazane w obecnym NPZ cele operacyjne i podejmowane $\mathrm{w}$ ich ramach działania nie zostały parametryzowane.

Biorąc pod uwagę znaczenie problemu nierówności w zdrowiu, zasadne jest szersze uwzględnienie jego kontekstu we wszystkich celach operacyjnych przyszłego NPZ oraz takie zaplanowanie działań ukierunkowanych na zmniejszenie narażenia społeczeństwa na największe zagrożenia zdrowia, by służyły one zmniejszeniu występujących nierówności.

\section{Właściwy dobór wskaźników monitorowania i ewaluacji}

Z przedstawionym problemem braku precyzyjnego wskazania docelowej (w perspektywie realizacji programu) wizji stanu czterech elementów składowych celu strategicznego silnie związana jest kwestia doboru wskaźników monitorowania i ewaluacji NPZ na poziomie celów operacyjnych i poszczególnych działań.

Analiza celów operacyjnych programu i zaproponowanych w nim mierników i wskaźników, które są objęte pomiarem, pokazuje brak miar efektu zdrowotnego i populacyjnego dla wielu $\mathrm{z}$ nich. Wynika to przede wszystkim $\mathrm{z}$ faktu nieprawidłowego doboru wskaźników lub posłużenia się wskaźnikami o zbyt ogólnym charakterze. W połączeniu z nieokreśleniem docelowej wartości poszczególnych wskaźników oznacza to również możliwość swobodnej interpretacji ich wartości w kategoriach oceny skuteczności realizowanych działań ${ }^{22}$.

Problemem pozostaje możliwość wykorzystania zapisanych w NPZ wskaźników i mierników do bieżącego monitorowania podejmowanych działań. Wartości wielu z tych wskaźników i mierników, choć ustalane cyklicznie w ramach

${ }^{22}$ P. Tyszko, M. Bogdan, Warunki sprawnościowe zwiąane ze struktura NPZ [w:] Ekspercka strategia wspomagania realizacji NPZ 2016-2020 w zakresie ograniczania społecznych nierówności w zdrowiu z wykorzystaniem funkcji i instytucji zdrowia publicznego, red. P. Tyszko, M. Bogdan, Konsorcjum Nauka i Zdrowie, Warszawa 2017, s. 51-56. 
„Programu badań statystyki publicznej”23, dostępne są jednak ze znacznym opóźnieniem. Istotnie ogranicza to możliwość bieżącego monitoringu podejmowanych działań, na rzecz oceny, która jest bardziej odległa w czasie i niepewna.

Dlatego też w kolejnym NPZ zasadne jest zwiększenie nacisku na właściwy dobór wskaźników dla poszczególnych celów programu i wykorzystanie naukowego dorobku zdrowia publicznego. W połączeniu z określeniem wartości docelowych wybranych wskaźników powinno to umożliwić zarówno bieżącą ocenę stopnia realizacji poszczególnych celów operacyjnych, jak i weryfikację, w kilkuletniej perspektywie czasowej, efektu zdrowotnego na poziomie populacji.

\section{Czynniki o charakterze zewnętrznym}

Czynników zewnętrznych warunkujących skuteczność NPZ jest wiele. Najważniejsze stanowią główne wyzwania systemu ochrony zdrowia, takie jak np.: nowa organizacja opieki szpitalnej i przewidywana zmiana roli podstawowej opieki zdrowotnej, zakres i sposób funkcjonowania Państwowej Inspekcji Sanitarnej oraz plany powstania nowego urzędu ds. zdrowia publicznego. Nowe regulacje powinny korespondować z ustawą o zdrowiu publicznym i NPZ.

Do tej grupy czynników należy również zaliczyć stosunkowo rzadko poruszane kwestie, takie jak dokonywanie oceny wpływu na zdrowie polityk sektorowych, zapewnienie odpowiednich środków na działania z zakresu zdrowia publicznego, kształcenie kadr zdrowia publicznego czy też określenia zasad ewaluacji podejmowanych działań.

\section{Zapewnienie sprawnej koordynacji działań i monitorowania NPZ}

Przed uchwaleniem ustawy o zdrowiu publicznym jedną z najbardziej oczekiwanych zmian w sposobie planowania i wdrażania polityki zdrowotnej było stworzenie warunków do skutecznej koordynacji podejmowanych działań. Potrzebę tę dostrzegano na poziomie centralnym, co częściowo realizowały poprzednie NPZ, ale przede wszystkim w odniesieniu do działań podmiotów należących do różnych sektorów, ze szczególnym uwzględnieniem aktywności w tym obszarze JST i organizacji pozarządowych ${ }^{24}$. Celem koordynacji miało być wykorzystanie efektu synergii i maksymalizacja osiągniętych wyników nawet w sytuacji dysponowania ograniczonymi zasobami. Służyć temu powinno odpowiednie bieżą-

${ }^{23}$ Rozporządzenie Rady Ministrów z 28 lipca 2016 r. w sprawie programu badań statystycznych statystyki publicznej na rok 2017, Dz.U. poz. 1426, ze zm.

${ }^{24}$ P. Tyszko i in., Elements of strategy supporting implementation of NHP 2016-2020, in particular in the scope of reducing geographical and social inequalities in health with the use of public health operations and institutions [w:] Expert strategy to support implementation of the NHP 2016-2020 for reducing geographical and social inequalities in health with the use of public health functions and institutions, red. P. Tyszko, M. Bogdan, Konsorcjum Nauka i Zdrowie, Warszawa 2016. 
ce zarządzanie programem, ze szczególnym uwzględnieniem ciągłego procesu monitorowania i ewaluacji realizowanych zadań. Działania takie są konieczne dla uelastycznienia programu - identyfikacji problemów i dokonania korekt na możliwie wczesnym etapie procesu zarządzania. Związana jest $\mathrm{z}$ tym również kwestia zapewnienia sprawnego przywództwa w wymiarze instytucjonalnym, a w miarę dostępności - także personalnym.

Możliwości zapewnienia sprawnego zarządzania programem są pochodną metod i narzędzi koordynacji przewidzianych w ustawie o zdrowiu publicznym zadań wynikających $\mathrm{z}$ NPZ oraz regulacji zawartych $\mathrm{w}$ innych aktach prawnych - odrębnie dla poziomu centralnego, regionalnego/lokalnego, jak również sposobu współpracy między „centrum a terenem” oraz współpracy z pomiotami spoza sektora publicznego.

Ustawa o zdrowiu publicznym stanowi, że zadania zdrowia publicznego będą koordynowane przez Ministra Zdrowia. W tym celu ustawa nałożyła na niego obowiązki, pośród których za najważniejsze z punktu widzenia zarządzania NPZ można uznać zapewnienie spójności zadań podejmowanych przez różnych realizatorów oraz sporządzanie okresowych informacji o zdaniach z zakresu zdrowia publicznego wraz z ich ewaluacją. Jednocześnie ustawa o zdrowiu publicznym przesądziła o utworzeniu dwóch ciał kolegialnych: Rady do spraw Zdrowia Publicznego i Komitetu Sterującego NPZ, wyznaczając tym samym instytucjonalne ramy procesu zarządzania NPZ. Należy przy tym zauważyć, że Komitetowi nie zostały przyznane uprawnienia decyzyjne, a tym samym jego rola może polegać przede wszystkim na usprawnianiu wymiany informacji pomiędzy faktycznymi decydentami - poszczególnymi członkami Komitetu (głównie ministrami).

Postanowienia ustawy o zdrowiu publicznym powinny zostać uzupełnione i uszczegółowione w NPZ. Niestety poza wskazaniem w części XI programu 22 zadań o charakterze koordynacyjnym, ewaluacyjnym i badawczym brak jest w nim określenia bliższego sposobu koordynacji całości programu. Komitet Sterujący NPZ został wskazany jako podmiot współpracujący z Ministrem Zdrowia w prowadzeniu monitorowania i ewaluacji programu, bez przypisania mu konkretnych zadań lub terminów.

Na skuteczność bieżącego zarządzania NPZ wpływają również określone w nim wskaźniki monitorowania i ewaluacji oraz sposób uzyskiwania informacji (sprawozdań) od realizatorów poszczególnych zadań. Przepisy ustawy o zdrowiu publicznym nałożyły obowiązek corocznego przedstawiania takich sprawozdań na organy administracji rządowej, agencje wykonawcze i inne państwowe jednostki organizacyjne. Zważywszy na terminy przekazywania tych sprawozdań i czas niezbędny do ich agregacji i analizy, jakiekolwiek podejmowane na ich podstawie działania będą odroczone w stopniu uniemożliwiającym dostatecznie szybką korektę programu. Szybkości podejmowania działań dostosowujących NPZ do zidentyfikowanych w procesie monitorowania uwarunko- 
wań nie sprzyja też stosunkowo długi, gdyż wynoszący dwa lata, okres pomiędzy przedstawianymi parlamentowi przez Radę Ministrów sprawozdaniami z realizacji zadań w obszaru zdrowia publicznego. Różni się to od dotychczasowej praktyki corocznego przedstawiania informacji o stanie realizacji polityk zdrowotnych (np. polityki antyalkoholowej czy antynarkotykowej). Oznacza też osłabienie bieżącego nadzoru nad realizacją działań z obszaru zdrowia publicznego i kontrolnej roli parlamentu, lecz przede wszystkim skutkuje znacznie rzadszym sporządzaniem całościowych ocen realizacji polityki publicznej w tym zakresie.

Powyższe spostrzeżenia uzasadniają obawy dotyczące skuteczności zaproponowanego modelu monitorowania oraz okresowej ewaluacji NPZ. Uzasadniają one oczekiwanie właściwego uregulowania tych kwestii w NPZ na lata 2021-2025.

\section{Urzeczywistnienie zasady Health in All Policies}

Zasada Health in All Policies („Zdrowie we wszystkich politykach”) wyznacza zarówno politykę, sposób podejścia, jak i strategię współpracy międzysektorowej, której celem jest poprawa zdrowia populacji przez uzyskanie pozytywnego wpływu na zdrowie inicjatyw podejmowanych w innych sektorach gospodarki. Zakłada ona uzyskanie tych efektów przy równoczesnej realizacji własnych celów sektorowych tych inicjatyw ${ }^{25}$. Na poziomie globalnym podejście to odzwierciedla przyjęta przez Zgromadzenie Ogólne ONZ „Agenda na rzecz zrównoważonego rozwoju 2030"26 (dalej: Agenda 2030), która formułuje 17 celów zrównoważonego rozwoju oraz 169 zadań służących realizacji tych zadań, które mają zostać osiągnięte do 2030 r. Do problematyki zdrowia odnosi się wprost cel nr 3 Agendy 2030 (Ensure healthy lives and promote well-being for all at all ages), aczkolwiek zagadnienia związane ze zdrowiem są obecne praktycznie we wszystkich innych obszarach działań wskazanych w tym dokumencie.

Na poziomie krajowym realizacja omawianej zasady, przez ujęcie jej w dokumentach formułujących politykę rozwoju, nie była dotychczas wystarczająca. Można było, co prawda, zaobserwować stały wzrost obecności zagadnień zdrowia $\mathrm{w}$ dokumentach przygotowywanych na poziomie centralnym, jak również wzrost liczby celów dotyczących stanu zdrowia w wojewódzkich strategiach rozwoju ${ }^{27}$.

${ }_{25}$ Adelaide Statement on Health in All Policies, moving towards a shared governance for health and well-being, Report from the International Meeting on Health in All Policies, Adelaide 2010, http://www.who.int/social_determinants/hiap_statement_who_sa_final.pdf [dostęp: 20 sierpnia 2018 r.].

${ }^{26}$ Rezolucja nr 70/1 Zgromadzenia Ogólnego ONZ z 25 września 2015 r. „Przekształcamy nasz świat: Agenda na rzecz zrównoważonego rozwoju 2030", http://www.un.org.pl/ agenda-2030-rezolucja [dostęp: 20 sierpnia 2018 r.].

27 P. Tyszko, M. Mińko, Przegląd krajowych strategii dotyczących zdrowia ludności, ze szczególnym uwzględnieniem nierówności w zdrowiu [w:] Projekt predefiniowany: ograniczanie społecznych nierówności $w$ zdrowiu, realizowany w ramach Programu Operacyjnego PL13, 
Jednakże brak było systemowego podejścia do kwestii oceny wpływu na zdrowie (health impact assesment) innych, „niezdrowotnych” polityk publicznych, które maksymalizuje pozytywne efekty zdrowotne lub przynajmniej minimalizuje oddziaływania negatywne, w celu wyboru takiego sposobu ich realizacji.

Przyjęcie ustawy o zdrowiu publicznym, ustawowe usankcjonowanie istnienia NPZ, a przede wszystkim uczynienie z NPZ rozporządzenia, czyli aktu prawnego powszechnie obowiązującego, dało podstawę do zmian w tym zakresie. Po pierwsze, w wyniku przyjętych w NPZ rozwiązań nie powinna już budzić wątpliwości konieczność zaangażowania oraz, co istotniejsze, odpowiedzialności za działania na rzecz zdrowia podmiotów spoza sektora ochrony zdrowia. Po drugie, wskazane w programie działania mogą i powinny stanowić punkt odniesienia dla oceny innych polityk publicznych. Tym samym stworzone zostały podstawy do urzeczywistnienia koncepcji międzysektorowych działań na rzecz zdrowia zawartej w haśle „Zdrowie we wszystkich politykach”28.

„Strategia na rzecz odpowiedzialnego rozwoju”29 (dalej: Strategia), będąca obecnie kluczowym dokumentem programowym w obszarze średnio- i długofalowej polityki gospodarczej państwa, wskazuje Agendę 2030 jako jedno z podstawowych zobowiązań warunkujących kierunki polityki rozwoju w Polsce. Szczególnie akcentowana jest zbieżność celu nr 1 Agendy 2030 (End poverty in all its forms everywhere) z celem głównym „Strategii na rzecz odpowiedzialnego rozwoju", jakim jest: tworzenie warunków dla wzrostu dochodów mieszkańców Polski przy jednoczesnym wzroście spójności w wymiarze społecznym, ekonomicznym, środowiskowym i terytorialnym ${ }^{30}$. Kwestie związane z szeroko rozumianym zdrowiem społeczeństwa nie zostały w Strategii wyodrębnione. Ujęto je w ramach działań nakierowanych na ochronę i podniesienie poziomu tzw. kapitału ludzkiego. Co istotne, odnotowano przy tym możliwość wpływania na stan zdrowia społeczeństwa działań podejmowanych w innych obszarach, np. w ramach rozwoju transportu drogowego. Warto również zauważyć, że Strategia wskazuje bardzo konkretny cel zdrowotny, który ma zostać uzyskany do roku 2030. Jest nim osiągnięcie wskaźnika przeciętnego trwania życia w zdrowiu (HLY) na poziomie 69 lat dla mężczyzn i 75 lat dla kobiet. Tym samym dokument o charakterze strategicznym jest bardziej precyzyjny niż mający charakter operacyjny NPZ.

Oceniając możliwość urzeczywistnienia zasady Health in All Policies, należy pamiętać, że skuteczność obecnego i przyszłego NPZ w wyznaczaniu „prozdro-

Poddziałanie 1.4, Międzysektorowa strategia ograniczania społecznych nierówności w zdrowiu, Konsorcjum Nauka i Zdrowie, Warszawa 2014.

28 A. Dębska, Zdrowie we wszystkich politykach - znaczenie i źródła [w:] Nie ma zdrowia bez badań $w$ dziedzinie zdrowia publicznego, red. D. Cianciara, Narodowy Instytut Zdrowia Publicznego - Państwowy Zakład Higieny, Warszawa 2014, s. 30-41.

29 „Strategia na rzecz odpowiedzialnego rozwoju do roku 2020 (z perspektywą do 2030 r.)", dokument przyjęty uchwałą Rady Ministrów 14 lutego 2017 r., MP poz. 260.

${ }^{30}$ Ibidem, s. 48. 
wotnego" sposobu urzeczywistniania innych polityk publicznych uwarunkowana jest ich precyzją w zakresie wskazania podmiotów mających realizować określone działania oraz określenia wyznaczonych tym wykonawcom konkretnych i mierzalnych celów.

\section{Zapewnienie ciągłości realizowanej polityki zdrowotnej}

Cechą charakterystyczną skutecznej polityki zdrowotnej jest zapewnienie ciągłości działań w ramach konkretnego cyklu polityki oraz między poszczególnymi cyklami. O tak rozumianej ciągłości, określanej również jako trwałość (sustainability), decydują czynniki organizacyjne (wewnątrz realizowanego programu) i kontekstowe (zewnętrzne wobec realizowanego programu), które pozwalają utrzymać w czasie działania programowe oraz wynikające z nich korzyści zdrowotne ${ }^{31}$. Ciągłość polityki zdrowotnej wyraża się między innymi: odpowiednią konstrukcją programu, zespołem oraz budżetem, strukturą administracyjną, powiązaniem z innymi programami oraz świadczeniami, społecznością, do której adresowane są działania ${ }^{32}$. Niestety w działaniach krajowych znaczenie trwałości wydaje się być niedoceniane.

Wewnętrzny komponent ciągłości NPZ wynika z przewidzianego w ustawie o zdrowiu publicznym minimalnego, 5-letniego, okresu jego obowiązywania. Zapewnia to średniookresową (operacyjną) stabilizację realizowanej polityki zdrowotnej, jednakże nie gwarantuje jej trwałości w dłuższej (strategicznej) perspektywie. Brak jest bowiem rozwiązań zapewniających ciągłość działań między poszczególnymi cyklami programowymi. Wynika to również z przywołanych już wcześniej problemów w zapewnieniu oceny rezultatów zdrowotnych oraz w skutecznym monitorowaniu i ewaluacji podejmowanych działań.

Biorąc pod uwagę, że określony w ustawie o zdrowiu publicznym czas obowiązywania NPZ ma charakter minimalny, teoretycznie nic nie stoi na przeszkodzie, by kolejne programy były przyjmowane na dłuższe okresy. Kierując się jednak dotychczasową praktyką określania polityki zdrowotnej na okresy około 5-letnie, zasadne wydaje się jednak przede wszystkim wprowadzenie w ustawie o zdrowiu publicznym obowiązku okresowego przeglądu realizowanego programu i uwzględnienia wyników tego przeglądu w planowaniu kolejnego cyklu programowego.

\section{Niezależna ewaluacja}

Jak wskazano we wstępie, polityka zdrowotna powinna stanowić nieprzerwany i powtarzający się ciąg cykli planowania, realizacji, monitorowania i ewaluacji.

${ }^{31}$ D. Cianciara i in., Trwałość samorzadowych programów zdrowotnych, „Hygeia Public Health" 2015, nr 50(1), s. 104-111.

${ }^{32}$ M.C. Shediac-Rizkallah, L.R. Bone, Planning for the sustainability of community-based health programs: conceptual frameworks and future directions for research, practice and policy, „Health Education Research” 1998, nr 13(1), s. 87-108. 
Monitorowanie i ewaluacja mają przy tym istotną rolę, gdyż ich prawidłowe przeprowadzenie daje podstawę do trafnego planowania kolejnego cyklu polityki ${ }^{33}$. Szczególne znaczenie ma tu ewaluacja - proces odnoszący się do całości zrealizowanych działań i oceniający ich skuteczność w realizacji wyznaczonych celów, podczas gdy monitorowanie służyć ma przede wszystkim bieżącemu zarządzaniu realizacją danej polityki.

W aktualnym stanie prawnym zarządzanie NPZ, obejmujące zarówno monitoring, jak i ewaluację, powierzone zostało Ministerstwu Zdrowia, które wspomagać mają dwa ciała: doradczo-opiniodawcza Rada ds. Zdrowia Publicznego i Komitet Sterujący NPZ. Ani ustawa o zdrowiu publicznym, ani NPZ nie wskazują zakresu i ram czasowych ewaluacji programu. Nie określają też modelu prowadzenia takiej oceny. Tymczasem zagadnienie to jest bardzo szeroko omawiane w literaturze przedmiotu. Są w niej formułowane konkretne zalecenia, co do sposobu ewaluacji polityki zdrowotnej. Odmiennie niż ma to miejsce w realizowanym obecnie NPZ, który zadania o charakterze ewaluacyjnym powierza Ministerstwu Zdrowia, zaleca się przede wszystkim tzw. zewnętrzną ocenę polityki zdrowotnej (external evaluation). Postulowane jest, aby oceny tej dokonywał podmiot zewnętrzny wobec organów władzy publicznej i innych podmiotów zaangażowanych w formułowanie oraz wdrażanie ocenianej polityki ${ }^{34}$. Za takim rozwiązaniem przemawia przede wszystkim brak przygotowania podmiotów publicznych do przeprowadzania badań oceniających skomplikowane polityki publiczne oraz zależność oceniającego od decydentów, realizatorów lub adresatów ocenianej polityki zdrowotnej ${ }^{35}$. Należy przy tym podkreślić, że warunkiem możliwości przeprowadzenia takiej zewnętrznej oceny byłoby precyzyjne określenie oczekiwanych, docelowych skutków ocenianego programu oraz zapewnienie istotnych, a przede wszystkim aktualnych danych o podejmowanych działaniach i ich rezultatach. Właściwa identyfikacja potrzebnych informacji wymagałaby przy tym włączenia przyszłego ewaluatora do wczesnych prac nad kolejnym NPZ.

\section{Podsumowanie}

Rok 2019 będzie czasem dyskusji nad kolejną edycją „Narodowego programu zdrowia”. Jak wielokrotnie podkreślano, niewątpliwą zaletą obowiązującego NPZ jest jego normatywny charakter. Wynika z niego wiele możliwości do podniesienia skuteczności realizowanej polityki zdrowotnej. Nie gwarantuje to jednak jej skuteczności. Jakkolwiek próba oceny obecnego NPZ byłaby w tej chwili przed-

${ }^{33}$ I. Reichardt, Ewaluacja jako narzędzie analizy polityk publicznych, „Zarządzanie Publiczne" 2011, nr 1(13), s. 11-23.

${ }^{34} \mathrm{~K}$. Buse, Addressing the theoretical, practical and ethical challenges inherent in prospective health policy analysis, „Health Policy and Planning” 2008, nr 23, s. 351-360.

${ }_{35}$ D.H. Gleeson, D.G. Legge, S. O’Neill, Evaluating health policy capacity, op. cit. 
wczesna oraz obarczona dużym ryzykiem błędu z uwagi na wskazane problemy $\mathrm{z}$ monitoringiem i ewaluacją tego programu, to możliwe jest sformułowanie postulatów wobec kolejnego NPZ. Postulaty te dotyczą procesu formułowania następnego NPZ, jego struktury wewnętrznej, jak i środowiska jego realizacji. Wskazują one na konieczność zmian w regulacjach oraz rozstrzygnięć o charakterze politycznym. Ich uwzględnienie powinno się przyczynić do powstania polityki zdrowotnej o spójnych, sparametryzowanych, precyzyjnie przypisanych realizatorom celach, sprawnie koordynowanej, dającej możliwości konsolidacji środków finansowych, efektywnie monitorowanej i ewaluowanej. W największym stopniu na poprawę realizacji przyszłego NPZ mogą wpłynąć wymienione poniżej działania.

- Utworzenie wyodrębnionego ośrodka koordynacji realizacji programu, np. w formie Urzędu do spraw Zdrowia Publicznego - celem zapewnienia profesjonalnej i nieprzerwanej, bieżącej koordynacji działań oraz umożliwienia wyodrębnienia na poziomie centralnym osób odpowiedzialnych za realizację programu. Cel ten mógłby również zostać osiągnięty przez powołanie przewidzianego w ustawie o zdrowiu publicznym pełnomocnika do spraw zdrowia publicznego. W każdej sytuacji wymagane byłoby zapewnienie takiemu ośrodkowi wyodrębnionego, stałego zaplecza eksperckiego, administracyjnego i finansowego oraz, co istotniejsze, realnych możliwości kształtowania prowadzonych działań, z czym wiązać się musi jakaś forma władztwa finansowego.

- Alokacja dodatkowych (nowych) środków finansowych oraz szersze wykorzystanie mechanizmu dofinansowania zadań z zakresu zdrowia publicznego podejmowanych przez jednostki samorządu terytorialnego - w celu przezwyciężenia najczęściej wskazywanej przeszkody w realizacji zadań zdrowia publicznego, jaką jest brak środków finansowych na zaspokajanie przez JST zbiorowych potrzeb mieszkańców w zakresie zdrowia publicznego ${ }^{36}$. Szersze wykorzystanie „wspierających” mechanizmów finansowych stanowić może efektywne narzędzie promocji myślenia o zdrowiu publicznym na poziomie regionalnym i lokalnym. Właściwe zaadresowane i uwarunkowane wsparcie umożliwiłoby natomiast zachętę do podejmowania działań spójnych z celami NPZ.

- Profesjonalna analiza efektów interwencji podejmowanych w ramach NPZ - celem wsparcia realizatorów zadań przez dostarczenie im informacji o zalecanym sposobie ich wykonywania. Dostarczenie realizatorom NPZ wiarygodnych, naukowo potwierdzonych informacji, np. w formie modelowych programów polityki zdrowotnej, jest szczególnie istotne z punktu widzenia zapewnienia równowagi między składowymi celu

36 NIK, Raport z kontroli „Wykonywanie wybranych zadań publicznych przez małe gminy", 2016, https://www.nik.gov.pl/kontrole/P/15/066/. 
strategicznego NPZ: 1) poprawy (średniego) stanu zdrowia społeczeństwa oraz 2) ograniczania społecznych nierówności w zdrowiu. Wobec braku możliwości zapewnienia na wszystkich poziomach realizacji polityki zdrowotnej odpowiedniej liczby wysoko kwalifikowanych specjalistów zdrowia publicznego udzielenie wsparcia eksperckiego z poziomu centralnego pozwoli uniknąć szkodliwego zjawiska „wywarzania otwartych drzwi".

- Precyzyjne sformułowanie celu przyszłego NPZ - tak by zawierał on informację o beneficjentach podejmowanych działań, przewidywanych korzyściach (wyrażonych przy użyciu mierzalnych, ilościowych kryteriów) i czasie, w którym wystąpią te korzyści. Działanie to jest konieczne zarówno z punktu widzenia prawnego - właściwego wykonania delegacji ustawowej do wydania przez Radę Ministrów rozporządzenia ws. NPZ, jak i dla zapewnienia efektywności programu - przez umożliwienie oceny skuteczności podejmowanych działań w realizacji wyznaczonego celu.

- Precyzyjne zaadresowanie i określenie charakteru zadań z zakresu zdrowia publicznego nałożonych na poszczególne szczeble JST - celem rozstrzygnięcia ich obligatoryjnego lub fakultatywnego charakteru przez zmianę postanowień ustawy o zdrowiu publicznym, oraz wyjaśnienia, czy realizatorem wskazanych w NPZ zadań mają być wszystkie JST, czy też jednostki o określonej liczbie ludności lub rozmiarze - przez doprecyzowanie postanowień NPZ odnoszących się do zadań JST.

- Przypisanie poszczególnych zadań zdrowia publicznego na poziomie centralnym do działów administracji rządowej - co umożliwi konkretne przypisanie odpowiedzialność podmiotom realizującym zadania przewidziane w NPZ i ułatwi realizację postulatu Health in All Policies przez silniejsze zaakcentowanie konieczności uwzględniania kwestii wpływu poszczególnych polityk publicznych na zdrowie społeczeństwa.

- Nadanie NPZ formy programu kroczącego - przez opracowanie kolejnych programów na dłuższy okres (10-15 lat - perspektywa strategiczna) przy ich regularnej weryfikacji (np. co 5 lat - perspektywa operacyjna). Umożliwi to uniknięcie ryzyka wynikającego z braku ciągłości i zmienności kierunków podejmowanych działań. Większa trwałość na poziomie celów strategicznych, w połączeniu z okresowym przeglądem służących ich realizacji celów operacyjnych i działań, pozwoli też na lepsze wykorzystanie dostępnych zasobów organizacyjnych i finansowych.

- Zapewnienie dostępu do wiarygodnych i aktualnych danych na potrzeby monitoringu i ewaluacji programu - przez wprowadzenie zmian w przepisach o statystyce publicznej oraz działania z zakresu informatyzacji systemu ochrony zdrowia. 


\section{Bibliografia}

Adelaide Statement on Health in All Policies, moving towards a shared governance for health and well-being, Report from the International Meeting on Health in All Policies, Adelaide 2010.

Buse K., Addressing the theoretical, practical and ethical challenges inherent in prospective health policy analysis, „Health Policy and Planning” 2008, nr 23, https://dx.doi. org/10.1093/heapol/czn026.

Cianciara D., Przyczyny i przyczyny przyczyn nierówności w zdrowiu, „Hygeia Public Health" 2015, nr 50(3).

Cianciara D. i in., Essential public health operations in the WHO European Region, „Postępy Nauk Medycznych" 2016, t. XXIX(5).

Cianciara D. i in., Trwałość samorządowych programów zdrowotnych, „Hygeia Public Health" 2015, nr 50(1).

Cianciara D., Grudziąż-Sękowska J., Dylematy oceny polityki zdrowotnej - przegląd piśmiennictwa międzynarodowego, „Hygeia Public Health” 2016, nr 51(3).

Dercz M., Izdebski H., Prawne aspekty organizacji i funkcjonowania systemu zdrowia publicznego w Polsce (Analiza prawa ustrojowego, materialnego i formalnego), Warszawa 2015.

Dębska A., Zdrowie we wszystkich politykach - znaczenie i źródła [w:] Nie ma zdrowia bez badań $w$ dziedzinie zdrowia publicznego, red. D. Cianciara, Narodowy Instytut Zdrowia Publicznego - Państwowy Zakład Higieny, Warszawa 2014.

Gleeson D.H., Legge D.G., O’Neill D., Evaluating health policy capacity: Learning from international and Australian experience, „Australia and New Zealand Health Policy” 2009, nr 6, https://dx.doi.org/10.1186/1743-8462-6-3.

Grudziąż-Sękowska J., Sękowski K., Analiza sprawnościowa możliwości realizacji NPZ aspekty prawne [w:] Ekspercka strategia wspomagania realizacji NPZ 2016-2020 $w$ zakresie ograniczania społecznych nierówności $w$ zdrowiu $z$ wykorzystaniem funkcji i instytucji zdrowia publicznego, red. P. Tyszko, M. Bogdan, Konsorcjum Nauka i Zdrowie, Warszawa 2017.

Grudziąż-Sękowska J., Sękowski K., Cianciara D., Ustawa o zdrowiu publicznym - nowa jakość?, „Postępy Nauk Medycznych” 2016, t. XXIX(5).

Izdebski H., Podstawy prawne ustroju zdrowia publicznego w Polsce, „Zdrowie Publiczne” 2001, nr 111(5-6).

Kellog W.K., Foundation, Using Logic Models to Bring Together Planning, Evaluation, And Logic Model Development Guide, January 2004, https://www.wkkf.org/resource-directory/resource/2006/02/wk-kellog-foundation-logic-model-development-guide.

Leśniewska A. i in., Działania powiatów w zakresie profilaktyki i promocji zdrowia w Polsce - w świetle badań ankietowych, „Hygeia Public Health” 2014, nr 49(3).

NIK, Raport z kontroli „Wykonywanie wybranych zadań publicznych przez małe gminy”, 2016, https://www.nik.gov.pl/kontrole/P/15/066/. 
NIK, Realizacja programów polityki zdrowotnej przez jednostki samorządu terytorialnego, informacja o wynikach kontroli, 2016, https:/www.nik.gov.pl/kontrole/P/15/063/.

Nosko J., O potrzebie ustawy o zdrowiu publicznym, „Zdrowie Publiczne” 2001, nr 111(2).

Oliver T.R., The politics of public health policy, „Annual Review of Public Health” 2006, nr 27, https://dx.doi.org/10.1146/annurev.publhealth.25.101802.123126.

Protokół ze spotkania dotyczącego przyszłości zdrowia publicznego w Polsce, http://www.prezydent.pl/archiwum-lecha-kaczynskiego/aktualnosci/rok-2008/ art,148,5,spotkanie-w-palacu-prezydenckim-dotyczace-przyszlosci-zdrowia-publicznego-w-polsce.html.

Reichardt I., Ewaluacja jako narzędzie analizy polityk publicznych, „Zarządzanie Publiczne" 2011, nr 1(13).

Shell S.F. i in., Public health program capacity for sustainability: a new framework, „Implementation Science” 2013, nr 8, https://dx.doi.org/10.1186/1748-5908-8-15.

Shediac-Rizkallah M.C., Bone L.R., Planning for the sustainability of community-based health programs: conceptual frameworks and future directions for research, practice and policy, „Health Education Research” 1998, nr 13(1), https://dx.doi.org/10.1093/ her/13.1.87.

Walt G., Gilson L., Reforming the health sector in developing countries: the central role of policy analysis, „Health Policy and Planning” 1994, nr 9(4), https://dx.doi. org/10.1093/heapol/9.4.353.

Tyszko P. i in., Elements of strategy supporting implementation of NHP 2016-2020, in particular in the scope of reducing geographical and social inequalities in health with the use of public health operations and institutions [w:] Expert strategy to support implementation of the NHP 2016-2020 for reducing geographical and social inequalities in health with the use of public health functions and institutions, red. P. Tyszko, M. Bogdan, Konsorcjum Nauka i Zdrowie, Warszawa 2016.

Tyszko P., Bogdan M., Warunki sprawnościowe związane ze strukturą NPZ [w:] Ekspercka strategia wspomagania realizacji NPZ 2016-2020 w zakresie ograniczania społecznych nierówności w zdrowiu z wykorzystaniem funkcji i instytucji zdrowia publicznego, red. P. Tyszko, M. Bogdan, Konsorcjum Nauka i Zdrowie, Warszawa 2017.

Tyszko P., Mińko M., Przegląd krajowych strategii dotyczących zdrowia ludności, ze szczególnym uwzględnieniem nierówności $w$ zdrowiu [w:] Projekt predefiniowany: Ograniczanie społecznych nierówności $w$ zdrowiu, realizowany w ramach Programu Operacyjnego PL13, Poddziałanie 1.4, Międzysektorowa strategia ograniczania społecznych nierówności $w$ zdrowiu, Konsorcjum Nauka i Zdrowie, Warszawa 2014.

\section{Akty prawne}

Ustawa z 11 września 2015 r. o zdrowiu publicznym, t.j. Dz.U. 2018, poz. 1492.

Rozporządzenie Rady Ministrów z 4 sierpnia 2016 r. w sprawie Narodowego Programu Zdrowia na lata 2016-2020, Dz.U. poz. 1492.

Rozporządzenie Rady Ministrów z 28 lipca 2016 r. w sprawie programu badań statystycznych statystyki publicznej na rok 2017, Dz.U. poz. 1426, ze zm. 
Uzasadnienie rządowego projektu ustawy o zdrowiu publicznym, druk sejmowy nr 3675/ VII kad.

„Narodowy program zdrowia na lata 1996-2005” przyjęty przez Ministra Zdrowia 3 września $1996 \mathrm{r}$.

Uchwała nr 90/2007 Rady Ministrów z 15 maja 2007 r. w sprawie „Narodowego programu zdrowia na lata 2007-2015".

Rezolucja nr 70/1 Zgromadzenia Ogólnego ONZ z 25 września 2015 r. „Przekształcamy nasz świat: Agenda na rzecz zrównoważonego rozwoju 2030".

Uchwała Rady Ministrów z 14 lutego 2017 r. „Strategia na rzecz odpowiedzialnego rozwoju do roku 2020 (z perspektywą do 2030 r.)”, MP poz. 260. 